\title{
Generation Z's Motivations for Following Brands on Facebook Brand Fan Pages: A Focus Group Study
}

\section{Gülçin İpek Emeksiz, Anadolu University, Turkey}

\begin{abstract}
The Generation Z, who use Facebook in order to get in touch with their friends, is a target audience for brands aiming to promote their products and services through Facebook marketing. But, Facebook marketing is a challenge for brands as it intervenes in this social domain. Therefore, whether Facebook marketing targeting these young people is an effective method or it is a waste of time for brands is a good question to ask. In order to find that the motivations of young people to interact with brands by liking brands' Facebook corporate brand fan pages were investigated in this research. With this aim, three qualitative focus group interviews were conducted with young students born after 1995, representing the Generation $\mathrm{Z}$ in Eskişehir, Turkey. Within the scope of the research, the number of brands that the participants like on Facebook and the reasons why they like Facebook corporate brand fan pages were primarily looked at. Then, the participants' interactions with brand generated content, brand representatives and other customers on Facebook brand fan pages were interrogated. Following that, the influence of Facebook marketing on purchasing products and services was examined. The research revealed that most of the young students are influenced by brand generated content on Facebook corporate brand fan pages and tend to shop as a result. The results gained in this study can be helpful to marketers in determining their communication strategies on Facebook brand fan pages.
\end{abstract}

Keywords: Generation Z, Facebook, Facebook marketing, Facebook brand fan pages 


\section{Online Brand Communities and the Generation $\mathrm{Z}$}

With the increase of social media usage worldwide, brands who want to strengthen their relationships with their existing and potential customers, have started to create online brand communities on social networking sites. Brand fan pages, which are created on the leading social networking site Facebook, are an example of a social network-based online brand community (Pöyry et al, 2013: 266). Companies who want to be visible use Facebook brand fan pages to create brand awareness. Facebook, the leading social networking site Facebook, is also a common point where young people meet to communicate with each other. Especially, the Generation $\mathrm{Z}$ born after 1995 and who are addicted to the Internet, social media and smart phones has a high percentage of Facebook usage that is $74 \%$ and Instagram usage that is $59 \%$ (Livemint, 2015). The Generation $\mathrm{Z}$ is evolving to become four in every ten consumers in the world's largest markets (Swathi, 2015). Therefore, the Genaration Z carries an importance for many brands as a target audience. For instance, in the U.S.A, Generation Z represents $\$ 44$ billion in annual purchasing power therefore it is important to know this group's social media habits and how they differ from the millennials, born between 1981 and 2000. (Andrus, 2015). Furthermore, the number of researches that were carried out regarding the interaction between brands and the Generation $\mathrm{Z}$ on Facebook are very limited in the literature. Therefore, why the Generation $\mathrm{Z}$ wants to be friends with brands on Facebook brand fan pages and wants to follow branded content are interesting topics to cover. Also, whether Facebook marketing is effective on young people using Facebook primarily to connect with their friends or a waste of time is a significant issue to cover, as well.

\section{Uses and Gratifications Theory}

Uses and gratifications theory is helpful in explaining online youth's motivations to use Facebook and interact with brands on Facebook. Blumler and Katz (1974), who said that people are not passive beings who are exposed to media, instead people use media to satisfy their specific needs, set forth the Uses and Gratifications Theory. The Uses and Gratifications Theory is based on the idea that individuals consume specific media according to their specific needs, which they are aware of. For instance, consistent with the research of Turkish Youth and Sports Ministry (2013) young Turkish people ranging in age 15 to 29 use social media the most for entertainment (60\%) and acquiring information (59\%). The other purposes that young Turkish people use social media for are spending free time (54\%), communication $(53 \%)$, tracking the social agenda / creating the social agenda $(51 \%)$, and education and 
research (47\%) (Turkish Youth and Sports Ministry, 2013: 73). When we look at why online youth interacts with brands online a Forrester report (2013) illustrates that US online youth interact with the brands on social networking sites as they like the idea of being associated with brands the most (58\%). They want to look at the content that companies post (\%48) and interact with other customers (\%48). Learning about the products or services (\%42) and sharing branded content with their friends and families (\%38) are the other factors that lead young people to like brands on social networking sites (Reed, 2013).

\section{Scope of the Study}

No research has been carried out concerning why Turkish online youth representing the Generation Z interacts with brands on Facebook. This research investigated the motivations of young Turkish people from the Generation $\mathrm{Z}$ for engaging with their favorite brands on Facebook. Accordingly, this research looked at what the motivations of young people representing Generation $\mathrm{Z}$ to like and to engage with their favorite brands on Facebook are. In other words, this research looked at how young Turkish people representing the Generation $\mathrm{Z}$ interacts with the brands that they like on Facebook. Brands also try to engage their existing and potential customers by sharing branded content about their products and services continually on their Facebook corporate brand fan pages. Thus, this research also examined whether Facebook marketing is an effective method on young Turkish people representing the Generation Z.

\section{Method}

With these goals in mind, three qualitative focus group sessions were conducted with young Turkish students born after 1995, representing the Generation $\mathrm{Z}$ and going to high school in Eskişehir, which is a northwestern city in Turkey. The qualitative research allows researchers to get at the inner experience of participants, to determine how meanings are formed through and in culture, and to discover rather than test variables (Corbin and Strauss, 2008: 12). The design of this qualititative research is phenomenology which tries to give a deeper understanding about the motivations of young people representing the Generation $\mathrm{Z}$ for following brands on Facebook brand fan pages.

The focus group interview sessions took place in a private teaching instutiton in Eskişehir where young students attended while preparing for the university entrance exam which they 
will take at the end of $12^{\text {th }}$ grade. Before, the focus group interviews permissions were taken both from the students and the private teaching instution providing a quiet classroom for the interviews. The students were selected on the condition that they had been following a company or had been friends with a company on Facebook. The students sat around a round table and the researcher moderated the focus group interviews. A structured interview technique was applied to all focus groups and open ended questions were asked to the participants.

The focus group interviews is a useful technique as there is a group interaction. The answers given to the questions are formed as a result of the interaction of the participants within the group, and some topics which doesn't come to mind in personal interviews can come to mind in focus group interviews with some participants' explanations; thus, it is possible for the other participants to make supplementary comments about the issue (Yıldırım and Şimşek, 2005: 151). In this case, the focus group interview sessions took approximately one hour and the interviews were voice recorded by the researcher. There were nine participants in the first focus group and the participants were attending to $10^{\text {th }}, 11^{\text {th }}$ and $12^{\text {th }}$ grades at different Anatolian or Technical high schools in Eskişehir. In the second focus group, there were nine participants and the participants were attending to $11^{\text {th }}$ grade at different Anatolian or Social Sciences high schools in Eskişehir. In the third focus group, there were eleven participants attending to $12^{\text {th }}$ grades at different Anatolian high schools in Eskişehir.

During the focus group interview sessions, while some of the participants abstained from explaining their opinions openly, the others took pleasure from discussing their point of views regarding following brands on Facebook corporate brand fan pages, actively. The participants agreed or disagreed with other participants' comments regularly, thus there was a good group discussion and interaction among the participants throughout the focus group interviews. In the analysis of the research, the technique of descriptive analysis was applied. First of all, the voice records were transcribed. Afterwards, the thematic codes that the data would be categorized were determined. Then the data was matched with the functional and meaningful thematic codes that they fit on a detailed focus group interview forms. Afterwards, the data was defined and supported with quotes. Lastly, the data was interpreted and linked together. Afterwards, for the reliability of the research, peer examination was requested from two research assistants at Anadolu University. In the peer examination, Miles and Huberman's 
intercoder reliability formula was used. Out of the 23 thematic codes, the two research assistants did not agree on 3 codes. After the calculation of the Miles and Huberman's intercoder reliability formula, consistency ratio of the research was found $88 \%$. Afterwards, the two research assistants and the researcher got together in a meeting and agreed on all thematic codes. After the changes were made, the reliability of the research increased to $100 \%$.

\section{Results}

\section{a. The number of years of being an user of Facebook}

The participants of the research representing the Generation $\mathrm{Z}$ met with Facebook, the leading social networking site, approaximately eight years ago in the year 2009 and they have been using Facebook actively since then.

\section{b. The time spent on Facebook}

According to the research of Turkish Youth and Sports Ministry the frequency of young people between 15 to 17 years old to use Facebook every day (83,9\%), a few times a day (69\%), once a day (14,9\%), a few times a week 9,5\%), and a few times a month $(6,8 \%)$. (Turkish Youth and Sports Ministry, 2013: 61). The statistics indicate that Turkish young people spend a lot of time on Facebook. In my research, the participants in focus group one are separated into two groups in terms of spending time on Facebook. While some of them spend 30 to 60 minutes in Facebook daily, some of them spend half an hour on Facebook weekly. The participants in focus group two spend more time on Facebook compared to the participants in focus group one. While some of them spend 15 minutes to 4 hours on Facebook daily, the rest of them spend two hours on Facebook weekly. Moreover, young people in focus group one highlighted that they also use other social networking sites such as Twitter and Instagram besides Facebook. The participants in focus group three emphasized that they log into Facebook in order to get rid of their boredom whenever they have their smart phones in their hands. Furthermore, they log into Facebook when they cannot sleep at nights. They spend 10 minutes to 2 hours on Facebook daily. Accordingly, while the participants in focus group two spend the most amount of time on Facebook, the participants in focus group one spend the least amount of time on Facebook. Also, I would like to underline that these students who participated into this research have been getting prepared for the university entrance exam which is a major student exam in Turkey. The participants 
have a heavy working schedule for their classes. Therefore, they have less free time compared to other students that are in the same age with them living in other countries.

\section{c. The technological devices used while accessing Facebook}

Most of the participants prefer using their smart phones primarily while accessing Facebook. It is observed that nearly all of the participants have smart phones and internet connection. They can connect to Facebook without location restriction with their smart phones. Other than smart phones, the participants also use laptops, ipads and desktop computers while connecting to Facebook.

\section{d. The reasons for using Facebook}

In my research, the participants in focus group one use Facebook to share photos, to gaze their friends' profiles, to keep up date with their friends' lives, to share funny and enjoyable posts, to track news, to follow sport clubs and celebrities, to spend their leisure time and to get in touch with their relatives. Futhermore, when they do not have any credits left in their mobile phones, they use the messenger application of Facebook to get in touch with their friends. However, the participants pointed out that they do not use the messenger application of Facebook very frequently as they prefer text messaging or WhatsApp operating in smart phones, instead. The participants in focus group two mainly use Facebook to look at the photos that their friends upload to Facebook and to communicate with their friends. Moreover, they use Facebook to be informed about the news and the results of football matches. Especially, looking at the photos of their friends and liking the photos are the common activities that all participants do. The participants prefer text messaging or WhatsApp rather than the messenger of Facebook. The participants in focus group three chiefly use Facebook to chat with their friends and to look at what their friends shared on Facebook. They said that they learn new information and interesting things through what their friends share on Facebook. Furthermore, they use Facebook to upload pictures, to share location and to look at funny caps. They also follow foreign celebrities and look at educative and scientific pages through Facebook.

\section{e. The number of brands liked on Facebook}

On Facebook, when somebody likes a brand fan page, then he or she starts to follow that brand. The posts of the brand continually comes to his or her newsfeed. In focus group one, the participants mostly like clothing or technology brands' Facebook fan pages. They follow four to seven brands on average. The clothing brands that they like are mainly sports brands. Nike and Adidas are the main brands that they follow. While girls prefer to follow women 
clothing brands such as Koton, Zara and Mango, they also follow the Facebook brand fan pages of virtual Turkish shopping stores such as Morhipo, Trendyol and Tozlu. In focus group two, the participants generally like ten brands on average, but some of the participants follow only two or three brands. Clothing brands such as Mavi, Adidas, Nike and Koton are the common brands that young peoplen in the focus group two follow on Facebook. In focus group three, the participants predominantly follow clothing and technology brands, as well. They like ten brands on average. International clothing brands such as Nike, Puma, Adidas, Mango, Zara and Turkish clothing brands such as Adl and Mavi are the common brands that they like on Facebook. Moreover, some of the participants follow technological brands such as Samsung and HP. Other brands that the participants like are from a variety of sectors such as food and beverage, media, and telecommunication. The other brands that they follow on Facebook are Cosmogirl, Daily Mail, Coca Cola, Eti and Turk Telecom.

\section{f. The reasons for liking corporate brand fan pages on Facebook}

A research conducted by Logan on young adults (2014) showed that perceived ease of use was the top motivation for young adults to follow brands both on Facebook and Twitter. Also, young adults were more likely to follow brands if they believe the activity was useful (Logan, 2014: 66 -67). By following brand fan pages on Facebook, the participants in my research gain insight about the variety of products that brands have. Additionally, they learn from which price the products are sold and have an opinion about what the new season trends are. Futhermore, by looking at brand posts of clothing brands, they have an idea about how to combine different clothes. The research of McCorkindale, Distaso and Sisco (2013) demonstrated that millennials engage with the companies for incentives such as discounts or special offers the most. The participants of McCorkindale et al's research showed that millenials were more likely to like an organization if it offered discounts (56\%) and product samples (40\%) (McCorkindale, Distaso and Sisco, 2013: 78-79). According to the statements of the participants in my research, young students representing the Generation $\mathrm{Z}$ like brand fan pages to be informed about the sales and campaigns that brands have, as well. Also, one of the participants in my research gets more information about the corporate social responsibility projects of the brands by following their brand fan pages on Facebook.

Kübra, Female, 18, Focus Group 1: "I can follow the new season products and see what is trendy or not."

Elif, Female, 16, Focus Group 1: "By looking at brands' Facebook pages, we can see the prices of their products." 
Nalan, Female, 20, Focus Group 3: "I would like to know what is fashionable in the new season. I have a color obsession. I would like to know which colors are hip. Thus, I follow the brands on Facebook."

Fatih, Male, 18, Focus Group 1: "I mostly follow brands on Facebook to catch up with the campaings and to be informed about the sales."

Ayşenur, Female, 18, Focus Group 2: "Sometimes they share the discounted products, thus I track them. Also, I can see the new models easily from Facebook."

Begüm, Female, 18, Focus Group 3: "Eti usually has creative ideas such as yellow bicycle which is about a corporate social responsibility project. I like Eti on Facebook to follow that."

\section{g. The relationship between positive brand experience and liking brands on Facebook}

Most of the participants in focus group three said that on Facebook they like the brands that they have had a positive brand experience before.

\section{h. Peer influence in liking corporate brand fan pages on Facebook}

According to the participants in focus group one, if they trust in the style of their friends, they start to follow the brand fan pages that their friends recommend on Facebook. Peer influence is influential for the participants in liking brand fan pages on Facebook. In focus group two, most of the participants also like brand fan pages with their friends' recommendations. However, some of the participants give importance to their own choices and decide themselves whether to like the brand fan pages on Facebook or not. In focus group 3, the participants stressed that they like brands on Facebook in accordance with their own choices. However some of them said that they are open to their friends' suggestions and they can like brands on Facebook with their friends' recommendations. Based on the statements of the participants, it looks like that there is a high tendency among young students to like brand fan pages with peer influence.

Kevser, Female, 18, Focus Group 1: "What I like on Facebook is the same as with my friends. Whichever brands my friends like on Facebook, I start to follow them, as well."

Kübra, Female, 18, Focus Group 1: "If I like the brands that my friends like on Facebook, I start to follow them too."

Aysema, Female, 18, Focus Group 1: "It depends on who says it. If it is one my friend whose style I trust, I start to follow the brand on Facebook. If it is somebody who I don't care, then there is no meaning to follow the brand on Facebook."

Ayşenur, Female, 18, Focus Group 2: “I didn't follow any brand from hearing my friends. It's all my own choices." 
Gizem, Female, 17, Focus Group 2: "Yes, if my friend is somebody whose style I like, I start to follow that brand on Facebook, as well."

Şevval, Female, 18, Focus Group 2: "I look at my friends' Facebook profiles. If there is a brand that I like on her/his profile, I start to follow it on Facebook."

Dilek, Female, 18, Focus Group 3: "No, the brands that I like on Facebook are all my own choices."

Alihan, Male, 18, Focus Group 3: "Of course I do with my friends' suggestions, I am somebody who is open to other ideas."

\section{i. Belonging to a Group by Liking the Corporate Brand Fan Pages on Facebook}

In focus group one, some of the participants said that they feel like they belong to a group by liking the Facebook pages of brands. However, according to these young people the precondition of feeling such a belonging is to shop from this brand before. In focus group one, the rest of the young people said that they do not feel such a belonging by liking brand fan pages on Facebook. In focus group two, young people didn't think that they belong to a group by liking Facebook brand pages and liking Facebook brand pages do not create a feeling of belonging for them. In focus group 3, most of the participants didn't think that they belong to a group by liking the Facebook pages of brands, either. However, one of the participant said that she feels like belonging to a group when she sees people liking the same posts with her.

Aysema, Female, 18, Focus Group 1: "If you shop from that brand frequently, you start to feel this way in awhile."

Büşra, Female, 16, Focus Group 1: "If I shop from that brand, I feel it."

Ayşenur, Female, 18, Focus Group 2: "I have never thought this way. I mainly look at the corporate brand fan pages on Facebook to spend my free time."

Sema, Female, 17, Focus Group 2: "I don't feel myself belonging to a group. I just like the products on Facebook pages of brands."

Dilek, Female, 18, Focus Group 3: 'No, I don't feel like belonging to a group. It's just something that I like."

Nalan, Female, 20, Focus Group 3: "I sometimes feel it. For instance, I follow some clothing brands on Facebook. When I see people liking the same posts with me, I feel like we have the same style and have the same opinions."

\section{j. Being a consumer of the brands liked on Facebook}

Most of the participants are consumers of the brands that they like on Facebook and they often shop from these brands. The participants don't follow the brands that they don't 
consume on Facebook. This finding is in parallel with the study of McCorkindale, Distaso and Sisco (2013) in which they found out that millennials were more likely to engage with organizations and corporations on social media if they were already engaged with the organization offline (Logan, 2014: 63).

\section{k. Being "cool" with the corporate brand fan pages liked on Facebook}

The brand fan pages that people like on Facebook are demonstrated on their profile. However, the participants thought that these corporate brand fan pages that they like on Facebook don't make them look cool because everybody can like these pages by pushing the like button.

\section{Whether the Facebook corporate brand pages reflect the image of the follower}

The brands that people like are shown on their profiles on Facebook. The participants in focus group one were in the opinion that if they follow different brands from their friends, this will show them differently and they will reflect their own style. In focus group two, some of the participants thought that the Facebook brand pages that they had liked give some hints about themselves to other people. They said that the Facebook brand pages they had liked reflect their personality and character. On the other hand, some of the participants said that their friends know them very well; therefore, they do not pay attention to these things. In focus group three, the participants said that what they like on Facebook brand pages reflect their tastes to other people especially concerning technology and clothes. However, there were some participants who didn't participate in this idea, as well.

Kübra, Female, 18, Focus Group 1: If we like the same things then it doesn't mean anything. But, if I like a brand fan page different from everybody else than it means something.

Aysema, Female, 18, Focus Group 1: We can think it this way. There is a shoe brand named Creepers Turkey. If follow this brand on Facebook while everybody else follow different brands, than this shoe brand reflects my style. If I am different than everybody else, then there is a meaning.

Gizem, Female, 17, Focus Group 2: Because every brand has a different style, I think it reflects our personality. This constitutes a foresight about us in other people's minds probably.

Sema, Female, 18, Focus Group 2: I don't think it tells anything about my personality. My friends know who I am. I don't think that they pay attention to that.

Yasemin, Female, 18, Focus Group 2: I think they shouldn't think this way, but my friends probably think that brands reflect a person's personality. 
Nalan, Female, 20, Focus Group 3: I think it tells something because everybody acts according to her/his own tastes.

\section{m. Defending the corporate brand fan pages on Facebook to other people}

In focus group one, some of the participants have an emotional bond with the brands that they like on Facebook. When they were asked whether they would defend the brands that they like on Facebook to other people, they said they would. Only a few of them said that, they wouldn't defend them. In focus group two, most of the participants were the defenders of the brands that they liked on Facebook, as well. They mentioned that they would defend the brands as they like their products, models and quality. In focus group three, the participants said that they would defend the brands that they use in daily life too. In addition, one of them said that they would defend the brands that they don't use but whose qualities they know. However, one of the participants said that he wouldn't get into discussions about defending brands as brands' main purpose is to consume people more.

Fatih, Male, 18, Focus Group 1: I will defend it. I can give a technological issue as an example. For instance, the device can be out of order and I would say look man this is a coincidence.

Aysema, Female, 18, Focus Group 1: I will defend it if somebody defames a brand that I like very much. I will say its good sides and defend it.

Ayşenur, Female, 18, Focus Group 2: I have an emotional bond. I will defend the brands in terms of quality.

Sema, Female, 17, Focus Group 2: I will defend them since I like all of their products. If somebody says that they are of poor quality I will be against him/her.

Nalan, Female, 20, Focus Group 3: I will defend a brand if I know its all details and even if I don't use it in daily life.

Alihan, Male, 18, Focus Group 3: I wouldn't defend them because their aim is to sell us and make us consume. I think getting into a discussion for this issue is meaningless.

\section{n. Recommending the corporate brand fan pages on Facebook to friends}

In focus group one, most of the participants recommends the brand fan pages that they like on Facebook to their friends. This indicates that electronic word of mouth is widespread among young people. However, some of them said that following a brand on Facebook is a personal decision. In focus group two, most of the young people don't suggest the brand pages that they like on Facebook to their friends. They are afraid of wearing the same clothes and they don't want to see the same thing on their friends and they want to be unique. In focus group 
three, the participants don't recommend the brand fan pages that they like to their friends. They said that they let their friends know about the brands when there is a campaign.

Aysema, Female, 18, Focus Group 1: There might be a corporate brand fan page on Facebook that is suitable for her/him but that she/he is not aware of. I will recommend this page to her/him.

Elif, Female, 16, Focus Group 1: She/He can either follow the brand on Facebook or not. This is a personal decision, I don't intervene in.

Sema, Female, 17, Focus Group 2: I don't generally recommend the brands that I like on Facebook to my friends. I don't want to be coinkydinky with the same clothes.

Furkan, Male, 17, Focus Group 2: I don't recommend. I don't want other people to have the same clothes with me.

Alihan, Male, 18, Focus Group 3: I don't usually recommend. When I see a campaign, I will tell him/her about the campaign.

\section{o. Liking and Commenting the Brand Posts on Facebook corporate brand fan pages}

In focus group one, the participants are generally not active in commenting on the posts that brands share. Even if they like them, they think that commenting on the brand posts will not contribute anything to them. This situation demonstrates that interaction is low between brands and young people in the sample. In focus group two, the participants mentioned that they like the branded content on Facebook either for no reason or when they see something different. When their friends like the branded content on Facebook, the participants are also motivated to like them. The rest of the participants said that they look at the branded content on Facebook brand fan pages but they do not like them. In focus group three, young people said that they would like to see branded content that draw their attention. Then, they are more inclined to like the posts that brands share.

Kevser, Female, 18, Focus Group 1: I just like them and look at the comments, but I don't make any comments.

Ülkü, Female, 17, Focus Group 1: I don't make any comments below the posts. Even if I say "beautiful", who is going to be influenced?

Ayşenur, Female, Focus Group 2: Yes, I like them, but I like them for no reason. I haven't commented on them until now because there are so many people that I do not know and I don't think there is a point. I don't think that anything will change when I write "beautiful".

Gizem, Female, 17, Focus Group 2: I can't say that I like them. I just look at them and then scroll down to see the next thing on my newsfeed. I don't see a point in making comments. 
Furkan, Male, 17, Focus Group 2: Nike usually share posts of sneakers on its Facebook brand fan page with Cristiano Ronaldo. My friends usually like these posts on Facebook. Then, I see that they liked them automatically in my newsfeed and I like them too. I don't comment because the comments appear on the top of the newsfeed and everybody sees them.

Yasemin, Female, 18, Focus Group 3: If it draws my interest, I like it.

Begüm, Female, 18, Focus Group 3: I don't make any comments because I don't read other people's comments. If I make comments, they won't read me. Therefore, there is no need.

\section{p. Sharing posts in the timeline of brands' corporate Facebook pages}

In focus group one, all of the participants said that they do not share any posts in the timeline of brands' corporate Facebook pages. Even if, some brands let their consumer to share posts on their timelines on Facebook, some brands do not let that because of their privacy settings. In focus group two and three, none of the participants share posts on brands' timelines on Facebook, as well. This shows that interaction between young people in the sample and brands is low. In fact, what drives people to share a brand's content is a topic coverd by Yuki (2015) and according to her findings people share a brand's content that makes him/her to look good (52\%) and to look intelligent (36\%). Furthermore, people share content that make them happy (\%47) and which creates excitement (\%24). Lastly, usefulness is another factor that drive people (especially women) to share a brand's content (\%48) (Yuki, 2015: 469).

\section{q. Getting in touch with brand representatives via Facebook}

In focus group one, the participants said that getting in touch with brand representatives via Facebook is not an effective method. They thought that brand representatives don't pay attention to them because the ones who tried before could not get answers to their complaints. They said that going to the physical stores and handling the issues face to face is much easier. This indicates that interaction between young people in the sample and brands is low on Facebook. In focus group two, the participants thought that getting in touch with brand representatives through Facebook isn't an effective method, as well. They said that brand representatives will either answer late or they won't care. The participants underlined that conveying their complaints or suggestions through social media will not lead to any results. They also stressed that going to the stores and handling the issues face to face is easier. However, some of the participants said that they can try getting in touch with brand representatives through social media. In focus group three, most of the young people mentioned that they won't get in touch with brand representatives through social media, as well. They said that getting in touch with brand representatives won't solve their problems. 
They solve their problems better by going to the physical stores. The statements of the participants show that interaction between young people in the sample and brands is low on Facebook.

Büşra, Female, 16, Focus Group 1: I haven't got in touch with them before. But, if I like a product a lot and if I can't find it in any stores, I'll write to them through Facebook.

Aysema, Female, 18, Focus Group 1: I find face to face communication more understandable therefore I prefer face to face communication.

Hande, Female, 17, Focus Group 1: I don't think that brand representatives care what is written by consumers on Facebook. Face to face communication is more effective.

Fatih, Male, 18, Focus Group 1: I tried before but it didn't work. They didn't give answers. I tried a lot. It was about a laptop broken down. I said give me an answer but there was no reply.

Ayşenur, Female, 18, Focus Group 2: I think that I can get a late response via social media. I don't think a complaint I made through Facebook will be taken care of. Therefore I find making complaints face to face more sensible.

Yasemin, Female, 18, Focus Group 2: I didn't have a need to get in touch with them before. But if I have to, I will get in touch with them through Facebook.

Dilek, Female, 18, Focus Group 3: I got in touch with them once. I asked them the size of a shoe. They wrote me back.

Alihan, Male, 18, Focus Group 3: I also got in touch with them once. It was about a tablet that I bought. I talked with the representatives but it didn't work well through Facebook. I brought the tablet back to the store that I bought it from and we fix the issue there.

r. Talking with other consumers on Facebook corporate brand fan pages.

In focus group one, the participants said that they don't talk with other consumers on Facebook pages of brands. Young people don't exchange their thoughts with other consumers. In focus group two, the participants don't talk with the other consumers on Facebook brand fan pages, either. In focus group three, the participants mentioned that they don't talk with other customers but read the comments of other customers. Some of the participants said that they prefer reading the customer reviews in forum sites rather than reading them on Facebook brand fan pages.

Dilek, Female, 18, Focus Group 1: I don't talk with other customers on Facebook corporate brand fan pages. 
Ayşenur, Female, 18, Focus Group 2: I have never talked but I look at the comments from time to time.

Gizem, Female, 17, Focus Group 2: I also read the comments. I look at the bad and good comments. But, I have never talked.

Yasemin, Female, 18, Focus Group 3: I don't talk, but I read the comments. Sometimes a lot of comments are made under a product or an advertisement. I take heed of everybody's opinion.

Alihan, Male, 18, Focus Group 3: I don't generally read comments on Facebook brand fan pages, but I usually do from forum sites.

\section{s. The relationship between liking brands on Facebook and purchasing products} afterwards

In focus group one, most of the young people emphasized that after following the brand fan pages on Facebook that they like, they tend to shop afterwards. Most of the participants had this experience two or three times before. After seeing the products on Facebook brand fan pages, they purchased them either online or by going to the physical stores. Therefore, Facebook marketing looks like an effective method on young people. In focus group two, the participants stressed that after liking brands on Facebook and following their posts for a period of time, they have a tendency to shop afterwards. They mentioned that the branded content on Facebook draw their attention and they want to look at the stores subsequently. Most of the participants had this experience at least two or three times before. The participants in focus group three also remarked that they tend to shop after following branded content on Facebook fan pages of brands.

Kübra, Female, 18, Focus Group 1: Of course, I did it twice. For instance, I liked a shoe on a Facebook brand fan page. It was the shoe that was in my mind. When I saw it on Facebook, I said that was it. Afterwards, I went to the store and purchased it.

Aysema, Female, 18, Focus Group 1: It happens to me too. Looking at products on brands' Facebook pages is easy and it is not exhausting. Once I liked a jacket on Facebook and bought it from a store afterwards.

Mert, Male, 17, Focus Group 1: First I look at the products through Facebook, then I purchase them from the internet. Buying from the internet is better than walking through.

Gizem, Female, 17, Focus Group 2: Yes, it happens. I can have an idea about what the stores are selling by looking at brands Facebook pages. Then I say, oh this store is selling this pants and this store is selling this shirt. Then I say it's good that I've seen these products on 
Facebook. Aftewards, I go to the stores and buy them. I had this experience three times before.

Ayşenur, Female, 18, Focus Group 2: Sometimes I saw that somebody wears something that I like. But I can't ask her. Then I saw the same thing on Facebook and learn its price. Afterwards, I went to the store and bought a couple of things that way. I had this experience two times before.

Berfin, Female, 18, Focus Group 3: I saw a Converse sneakers on its Facebook page once and purchased it from a Converse store afterwards.

Yusuf, Male, 18, Focus Group 3: I think it directs us to purchasing behavior. We see the products on Facebook and like them. Their colors and qualities draw our attention. Then, I want to look at them at stores.

\section{t. Whether banner advertisements on Facebook corporate brand fan pages draw attention or give disturbance}

Most of the participants in focus group one find banner advertisements on Facebook very irritating. They highlighted that banner advertisements pop up and it is hard to close them. Some of the participants said that even though they don't find banner advertisements irritating, banner advertisements don't draw their attention. Accordingly, banner advertisements on Facebook brand fan pages don't draw the attention of young people in the sample. In focus group two, the participants don't pay attention to banner advertisments, as well. Since they connect to Facebook from their mobile phones most of the time, banner advertisement don't show up on their Facebook pages. As they see the advertisements when they connect to Facebook from their laptops, they said that they find banner advertisements irritating. Therefore, they prefer not looking at them and they close them instead. In focus group three, most of the participants stressed that they ignore the banner advertisements on Facebook corporate brand fan pages. They mentioned that these advertisements are redundant and create a visual pollution. Some of the participants said that they don't mind banner advertisements and they look at them to pass time. Since banner advertisements are targeted ads, they are related with the things that they like. One of the participant said that she shares her ten minutes every day by looking at banner advertisements on Facebook brand fan pages.

Büşra, Female, 16, Focus Group 1: Banner ads draw my attention. Whatever it is on the banner ad, I look at it.

Fatih, Male, 18, Focus Group 1: I find them very irritating. I try to close them every time. I try to ignore them. 
Mert, Male, 17, Focus Group 1: I find banner ads disruptive. When the mouse clicks, a lot of things pop up and then I try to close them for a long time.

Ayşenur, Female, 18, Focus Group 2: Sometimes, they share campaings on banner ads. When I see incredible discounts, they draw my attention. Something that costs 50 Turkish Liras can be promoted much cheaper on banner ads.

Yasemin, Female, 18, Focus Group 2: As I connect to Facebook from my smart phone, I don't come across with banner ads.

Furkan, Male, 17, Focus Group 2: They never draw my attention. I find them irritating. I close them all the time.

Nurşirin, Female, 19, Focus Group 3: Banner ads create a visual pollution for me. I don't like them. I ignore them most of the time.

Nalan, Female, 20, Focus Group 3: They draw my attention. I spend my ten minutes looking at them as they are target ads related with my interests.

\section{u. Things that young people would like to see on Facebook corporate brand fan pages}

In focus group one, most of the participants like fashion brands. However, none of the female and male participants in the focus group feel content as idealized human bodies different from the standart human body size are portrayed on brands' fan pages on Facebook. As the female participants are not $1.80 \mathrm{~cm}$ tall and do not have a model's body size, they said that they cannot visualize how the clothes that they see on Facebook brand fan pages fit on them. The female participants mentioned that pictures of models do not look real. Therefore, the standart Turkish women size should be considered. The male participants remarked that instead of muscular men bodies showing that they have been working out, the standart Turkish men size should be used. As it is seen, both female and male participants compare their body sizes with these idealized model bodies and feel bad about themselves. The participants in focus group two want to see the campaigns and new products of brands on their Facebook brand fan pages. They said that brands should continually let their followers know about the promotions and sales. The participants in focus group three want brands to display on their Facebook brand pages which products are sold the most. In addition, the participants in focus group three want to see the slogans and creative ideas of brands on their Facebook brand fan pages.

Büşra, Female, 16, Focus Group 1: I wish they share the pictures of normal people instead of beautiful models so that we can see how the clothes will look on us. Instead of $1.80 \mathrm{~cm}$ tall models, they should prefer models who are $1.65 \mathrm{~cm}$ tall. 
Mert, Male, 17, Focus Group 1: I see something that I can buy on a Facebook page of a brand. But the model who wears it has a triangular body shape. The model's arms are muscular. If I purchase that piece, I will be lost within it. The model is a sportsman of 5 years. I am a sportsman of six months. The brands display models who are above the average of a normal person's size.

Gizem, Female, 17, Focus Group 2: Brands do not share every product that they have in their physical stores even in their websites. I want brands to continually share their new products on their Facebook pages because they usually do not update their websites.

Dilan, Female, 17, Focus Group 2: I look at brands' Facebook pages when I decide to buy something. They show a product on their Facebook page but when I go to the store it is not present. Why do they show a product that is not present on their Turkish Facebook page?

Berfin, Female, 18, Focus Group 3: I would like to see their new campaigns on their Facebook pages.

Nalan, Female, 20, Focus Group 3: I would like to see their slogans and their creative ideas on their Facebook pages.

Fatmanur, Female, 18, Focus Group 3: I would like to see the products which are sold the most. This way, I can learn which style people like the most.

\section{v. Whether Facebook marketing is effective on young consumers or not}

In focus group one, some of the participants think that Facebook marketing is effective on young people, thus marketers should invest in it more. In focus group two, while some of the participants said that Facebook marketing is effective on young people, others pointed out that the new trend is Instagram. Thus marketers should invest in Instagram more. In focus group three, the participants underlined that Facebook marketing is effective on young people as young people spend most of their time on Facebook. However, some young people said that marketers should use other social media tools other than Facebook such as Instagram as Facebook is not fashionable any more. The participations who are the social media generation thinks that social media marketing leads to consumption.

Kübra, Female, 18, Focus Group 1: It think it affects because we first look at the posts on Facebook. Then, we look at the websites to see whether the products are available.

Şevval, Female, 18, Focus Group 2: I think Instagram marketing is more effective because most of the people that are around me are on Instagram.

Furkan, Male, 17, Focus Group 2: I think marketers should be canalized to other social networking sites. People share empty words on Facebook and Facebook turned into a place 
where idleness people hang out. Facebook is out of date. It's a place where our relatives hang out.

Yusuf, Male, 18 Focus Group 3: Of course, it is effective. Most of the young people pass their whole time on Facebook. I think it is a very influential.

Dilek, Female, 18, Focus Group 3: I think it is effective but it is not enough. They should supplement Facebook marketing with other social media tools such as Instagram. This way, it will be more effective.

Begüm, Female, 18, Focus Group 3: I think it affects. We are all kids of social media generation. Facebook marketing leads to consumption.

Fatmanur, Female, 18, Focus Group 3: I think it is effective because we see the posts on Facebook and they somehow stay in our minds.

\section{w. Shopping through Facebook}

Most of the brands in Turkey do not have a shopping option on their Facebook brand fan pages. When the participants were asked whether they consider doing shopping from Facebook brand fan pages, they said that they have doubts. Most of the participants mentioned that they don't find shopping through Facebook safe. Thus, they will prefer websites. Also, some of them said that doing shopping from pyhsical stores by wandering arounds is more fun and meaningful. Although, some of the participants said that doing shopping through Facebook with a few clicks will be very easy and convenient. In focus group 2, the participants said that they won't do shopping through Facebook if such an opportunity appears in the future. One of the participant said that she did shopping via Instagram. However she had difficulties in terms of getting the right size and changing the product. The participants said that they prefer touching and trying the product that they will buy. They stressed that shopping through the internet is not trustable. Although, some of the participants mentioned that they do shopping from virtual shopping sites such as Morhipo or Trendyol. Also, coming across with a fake Facebook account and giving their credit card number to this fake site is another element that deters young people from shopping through Facebook. In focus group three, most of the participants said that they don't find shopping from Facebook safe as well. The participants prefer shopping from physical stores rather than the internet and they said that they may do shopping from Facebook if there will be an option to pay from the door.

Fatih, Male, 18, Focus Group 1: I will buy probably. You can order a pizza with four clicks. Why not order something with four clicks to our door? 
Hande, Female, 17, Focus Group 1: I wouldn't buy. It's not safe and it isn't fun. Shopping is something everybody likes. I find shopping by wandering around more enjoyable. It's more meaningful.

Ayşenur, Female, 18, Focus Group 2: Once I did from Instagram. I bought a shirt but it was small. I had difficulty in changing it afterwards. Thus, I don't think I will buy something through Facebook.

Gizem, Female, 17, Focus Group 2: It needs to prove me that it is trustable, then I can buy from it. I do shopping from virtual shopping sites such as Morhipo and when I have a problem, they can solve it.

Şevval, Female, 18, Focus Group 2: If it gives me guaranty that it will solve my problem when I have a problem, I will prefer doing shopping through Facebook.

Berfin, Female, 18, Focus Group 3: I wouldn't buy either. Once I bought a shoe from the internet. I recieved something different from what I saw in the picture on the website. I had difficulty in returning it.

Begüm, Female, 18, Focus Group 3: As long as there is a payment option at the door, I will buy through Facebook.

\section{Discussion}

According to the results of this research, the motivations of young Turkish students representing the Generation $\mathrm{Z}$ to follow brand fan pages on Facebook are learning about the campaings and promotions and seeing the new products and services with their prices. One of the significant finding of this research is that most of the participants in the research were inclined to shopping after following the brand fan pages on Facebook that they liked. They had this experience two or three times before as they spend most of their time on Facebook. Thus, most of the participants highlighted that Facebook marketing is effective on young people. They stressed that Facebook marketing targeting the Generation $\mathrm{Z}$ is not a waste of time for brands. However, the participants also pointed out that companies should use other social networking tools such as Instagram which is the trendiest social media tool among young students. The participants in the research also want brands to display every product that they have in their physical stores on their Facebook page but they don't want idealized human bodies displaying the products. Instead, they would like to see average human bodies on brands' Facebook pages. Most of the participants were hesitant about shopping through Facebook. They assume that shopping from Facebook will not be safe. However, some of 
them think that if there will such an option in the future, they are willing to try it as it will be more convenient and fast. This study showing the motivations of young Turkish student representing the Generation $\mathrm{Z}$ to follow brand fan pages on Facebook will be helpful to marketers in determining their communication strategies on Facebook brand fan pages. 


\section{References}

Andrus, A. (2015). Gen Z vs. Gen Y: Does the Hype Add Up? SproutSocial. http://sproutsocial.com/insights/gen-z-vs-gen-y/ Access: March 2, 2016.

Blumler J. G. \& E. Katz (1974): The Uses of Mass Communication. Newbury Park, CA: Sage.

Corbin, J. and Strauss, A. (2008). Basics of Qualitative Research. Sage: Thousand Oaks, California.

Livemint (May 29, 2015). Mary Meeker's 2015 Internet Trends Report highlights key digital trends http://www.livemint.com/Industry/JLUmevbvpJyEdbgMBVLXhN/Indialeading-market-in-both-Internet-and-smartphone.html, Access: March 4, 2016

Logan, K. (2014). Why Isn't Everyone Doing It? A Comparison of Antecedents to Follow Brands on Twitter and Facebook, Journal of Interactive Advertising, 14 (2): 60 -72.

McCorkindale, T., DiStaso, M. W., Sisco, H. F. (2013). How Millenials are Engaging and Building Relationships with Organizations on Facebook, The Journal of Social Media in Society, 2 (1): 66-87.

Pöyry, E., Parvinen, P., and Malmivaara, T. (2013). Can we get from liking to buying? Behavioral differences in hedonic and utilitarian Facebook usage, Electronic Commerce Research and Applications, 12, 224-235.

Reed, F. (2013). What Do Youth Expect From Brands in Social Media? Marketing Pilgrim. http://www.marketingpilgrim.com/2013/09/what-do-youth-expect-from-brands-insocial-media.html, Access: March 7, 2016

Swathi, R. M. (October 13, 2015). Generation Z: 80\% Use Social Media Daily, 65\% Share Content http://dazeinfo.com/2015/10/13/generation-z-80-use-social-media-daily-65share-content-infographic/Access: March 9, 2016

Türkiye Cumhuriyeti Gençlik ve Spor Bakanlığı (2013). Gençlik ve Sosyal Meyda Araştırma Raporu, T.C Gençlik ve Spor Bakanlığı Eğitim, Kültür ve Araştırma Yayın No:79, Gençlik Araştırmaları Yayın No: 4, Afşar Matbaacılık: Ankara.

Yıldırım, A. and Şimşek, H. (2005). Sosyal Bilimlerde Nitel Araştırma Yöntemleri, Seçkin Yayınc1l1k: Ankara.

Yuki, T. (2015). What Makes Brands' Social Content Shareable on Facebook? Journal of Advertising Research, DOI: 10.2501. 